\title{
The 2015 British General Election: a Convergence in Scottish Voting Behaviour?
}

Les élections législatives britanniques de 2015, signe d'une convergence des comportements électoraux des Écossais?

\section{Nathalie Duclos}

\section{(2) OpenEdition}

\section{Journals}

Electronic version

URL: http://journals.openedition.org/rfcb/639

DOI: $10.4000 / \mathrm{rfcb} .639$

ISSN: 2429-4373

Publisher

CRECIB - Centre de recherche et d'études en civilisation britannique

Electronic reference

Nathalie Duclos, «The 2015 British General Election: a Convergence in Scottish Voting Behaviour? », Revue Française de Civilisation Britannique [Online], XX-3 | 2015, Online since 01 December 2015, connection on 30 April 2019. URL : http://journals.openedition.org/rfcb/639; DOI : 10.4000/rfcb.639

This text was automatically generated on 30 April 2019.

\section{$\Theta \Theta \Theta \Theta$}

Revue française de civilisation britannique est mis à disposition selon les termes de la licence Creative Commons Attribution - Pas d'Utilisation Commerciale - Pas de Modification 4.0 International. 


\title{
The 2015 British General Election: a Convergence in Scottish Voting Behaviour?
}

\author{
Les élections législatives britanniques de 2015, signe d'une convergence des \\ comportements électoraux des Écossais?
}

Nathalie Duclos

\section{Introduction}

Since the 2015 British General Election, the SNP has repeatedly underlined how exceptional and historic the result was in Scotland. In the Guardian on 9 May, just after the election, SNP leader and Scottish First Minister Nicola Sturgeon noted that:

The word historic is overused when it comes to elections and political events - but what we have witnessed in the past few days is properly deserving of that description. Whatever the future of Scottish and UK politics, the events of the early hours of Friday are a moment in time that will be studied and debated for decades to come. ${ }^{1}$

To her party, the exceptional outcome of the election in Scotland now gives the British Government and Parliament a moral obligation to agree to the SNP's demands, especially, for the time being, its demands on further powers for Scotland.

That is what several SNP MPs argued in the House of Commons during the Second Reading of the Scotland Bill on further devolution of powers, one month after the election. Ian Blackford, for instance, declared: "The SNP won the election in Scotland conclusively. We stood on a mandate of powers for a purpose. Why does the Secretary of State [for Scotland, David Mundell] not deliver what the people of Scotland voted for: a powerhouse Parliament with full economic powers?" "Similarly, SNP group leader Angus Robertson stated: "The Bill is a response to the referendum, but we now need an adequate response to the general election and the clear mandate for more powers that was delivered." In summary, the SNP is arguing that the General Election result was so conclusive in Scotland that the British 
Parliament should take it into account when voting on the Scotland Bill, considering that there are only 59 Scottish seats in the House of Commons, which makes it structurally impossible for Scottish MPs to force a majority vote, despite their near unanimity. As Angus Robertson put it during the same debate, "[t]he people have spoken, and the UK Government should respect their choice." ${ }^{4}$

One might disagree with the SNP's assessment of what the mandate which it was given implies, but it is undeniable that the General Election result was historic, in at least two respects. First of all, beyond the fact that the SNP won a majority of Scottish seats in a General Election for the first time in its history, what is truly exceptional is that the Labour Party did not win a majority for the first time in more than half a century. Labour had won every single General Election in Scotland since 1959 in terms of seats, or since 1964 in terms of both seats and votes. Secondly, the 2015 outcome was historic because of the margin of the SNP's victory: the SNP won all seats in Scotland bar three, one for each of the big Unionist parties (Labour, the Conservatives and the Liberal Democrats). ${ }^{5}$ In other words, Labour didn't just lose in Scotland in 2015: it lost all of its seats except one, and a rather unlikely one at that (Edinburgh South). Moreover, the SNP won exactly half of the popular vote (50.0\%), which no party had managed to do in more than half a century. The Liberals had regularly won more than $50 \%$ of the vote in Scotland before 1918, and the Conservatives had won $50.1 \%$ in 1955 , but Labour, despite its nearhegemony in Scotland since the 1960s in terms of seats won, never managed to reach 50\% of the popular vote, although it did come close with $49.9 \%$ in 1966.

This paper will not argue that the 2015 election outcome in Scotland was not historic: it undeniably was. Rather, the aim of this paper is to put this outcome into context and into perspective, through an analysis of General Election results in Scotland over the years, and then through a comparison between those results and Scottish Parliament election results. It will be argued that the 2015 election outcome was exceptional for another, less obvious reason, namely that it was the result of a convergence in voting behaviour in Scotland for General Elections and for Holyrood elections (though not - or not yet - for other types of elections), something which had not happened since the early days of devolution in Scotland.

General Election results in Scotland since 1997

Table 1- General Election results in Scotland since 1997, in terms of seats

\begin{tabular}{|c|c|c|c|c|c|}
\hline & $\begin{array}{l}1997 \\
(72 \text { seats })\end{array}$ & $\begin{array}{l}2001 \\
(72 \text { seats })\end{array}$ & $\begin{array}{l}2005 \\
(59 \text { seats })\end{array}$ & $\begin{array}{l}2010 \\
(59 \text { seats })\end{array}$ & $\begin{array}{l}2015 \\
(59 \text { seats })\end{array}$ \\
\hline Labour & $\begin{array}{l}56 \text { seats/ } \\
78 \% \text { seats }\end{array}$ & $\begin{array}{l}56 \text { seats } / \\
78 \% \text { seats }\end{array}$ & $\begin{array}{l}41 \text { seats/ } 69 \% \\
\text { seats }\end{array}$ & $\begin{array}{l}41 \text { seats } / 69 \% \\
\text { seats }\end{array}$ & $\begin{array}{l}1 \text { seat/ } \\
2 \% \text { seats }\end{array}$ \\
\hline Lib Dem & $\begin{array}{l}10 \text { seats/ } 14 \% \\
\text { seats }\end{array}$ & $\begin{array}{l}10 \text { seats/ } 14 \% \\
\text { seats }\end{array}$ & $\begin{array}{l}11 \text { seats/ } \\
19 \% \text { seats }\end{array}$ & $\begin{array}{l}11 \text { seats/ } \\
19 \% \text { seats }\end{array}$ & $\begin{array}{l}1 \text { seat/ } \\
2 \% \text { seats }\end{array}$ \\
\hline SNP & $\begin{array}{l}6 \text { seats/ } \\
8 \% \text { seats }\end{array}$ & $\begin{array}{l}5 \text { seats/ } \\
7 \% \text { seats }\end{array}$ & $\begin{array}{l}6 \text { seats/ } \\
10 \% \text { seats }\end{array}$ & $\begin{array}{l}6 \text { seats/ } \\
10 \% \text { seats }\end{array}$ & $\begin{array}{l}56 \text { seats/ 95\% } \\
\text { seats }\end{array}$ \\
\hline Conservative & $\begin{array}{l}0 \text { seat/ } \\
0 \% \text { seats }\end{array}$ & $\begin{array}{l}1 \text { seat/ } \\
1 \% \text { seats }\end{array}$ & $\begin{array}{l}1 \text { seat/ } \\
2 \% \text { seats }\end{array}$ & $\begin{array}{l}1 \text { seat/ } \\
2 \% \text { seats }\end{array}$ & $\begin{array}{l}1 \text { seat/ } \\
2 \% \text { seats }\end{array}$ \\
\hline
\end{tabular}


Table 1 presents General Election results in Scotland since 1997. It starts in 1997 because those results will then be compared to Scottish Parliament election results, of which there were none before 1999. It displays the number of seats won by each party, as well as the share of seats which this represents, as there was a substantial reduction in the number of Scottish seats in the House of Commons (from 72 to 59) on the occasion of the 2005 General Election.

Over the 1997-2015 period, General Election results in Scotland were extremely stable until the historic 2015 result, if only because Scots systematically gave seats to the same parties in the same order every time. From 1997 to 2010, Labour always came first, the Liberal Democrats second, the SNP third and the Conservatives fourth. In summary, what is noteworthy is not just that Labour always came first, but also that the SNP never managed to come better than third. Looking at the table more closely, one sees that the results were almost identical in 1997 and 2001 (there was one seat change in the whole of Scotland) and that they were completely identical in 2005 and 2010 (there were no seat changes at all). In other words, between 1997 and 2010, the only significant change happened on the occasion of the 2005 election, not so much because Scots modified their voting behaviour, but for a structural reason, namely the reduction in the overall number of Scottish seats in the Commons, the main consequence of which was a reduction in the number of Labour seats (from 56 to 41 ).

The overall impression of stability from 1997 to 2010 diminishes a little if one considers General Election results not in terms of seats, but in terms of votes, as table 2 makes clear.

Table 2- General Election results in Scotland since 1997, in terms of votes (\%)

\begin{tabular}{|l|l|l|l|l|l|}
\hline & $\begin{array}{l}1997 \\
(72 \text { seats })\end{array}$ & $\begin{array}{l}2001 \\
\text { (72 seats) }\end{array}$ & $\begin{array}{l}2005 \\
\text { (59 seats) }\end{array}$ & $\begin{array}{l}2010 \\
\text { (59 seats) }\end{array}$ & $\begin{array}{l}2015 \\
\text { (59 seats) }\end{array}$ \\
\hline Labour & 45.6 & 43.3 & 39.5 & 42.0 & 24.3 \\
\hline Lib Dem & 13.0 & 16.3 & 22.6 & 18.9 & 7.5 \\
\hline SNP & 22.1 & 20.1 & 17.7 & 19.9 & 50.0 \\
\hline Conservative & 17.5 & 15.6 & 15.8 & 16.7 & 14.9 \\
\hline
\end{tabular}

Contrary to what was the case in terms of seats, Scottish voters' party rankings were not always the same depending on the years. Labour still always came first, but the SNP did not always come third (as it did in terms of seats): it managed to come second in three out of the four elections concerned (in 1997, 2001 and 2010). Moreover, whereas there were almost no seat changes except when the electoral boundaries were redrawn in 2005, the share of the vote won by each party did evolve over the years. However, it did not evolve in the way that might be expected considering the 2015 election result. Where one might expect a steady decline in Labour votes and a steady rise in SNP votes over the years (which is what has characterised Scottish Parliament elections, as will be seen later), what one gets instead is two parallel curves for Labour and the SNP until 2010. From 1997 to 2005 , there was a slight but steady decline in the percentage of votes won by both parties, followed by a rise in both parties' share of the vote in 2010. In other words, only between 2010 and 2015 did the share of the votes won by the two parties follow a completely different curve. 
In summary, General Election results in Scotland were very stable between 1997 and 2010. Labour always came first, in terms of both seats and votes, and by far (winning between $69 \%$ and $78 \%$ of all seats, and between $39.5 \%$ and $45.6 \%$ of the vote). As for the SNP, it always came third in terms of seats, and came either third or second in terms of votes (winning either 5 or 6 seats, and between $17.7 \%$ and $21.1 \%$ of the vote). Until 2015, the SNP had never in its existence managed to win more than 11 seats in a General Election, as table 3 shows.

Table 3- SNP results in General Elections

\begin{tabular}{|l|l|l|}
\hline & Seats & Votes (\%) \\
\hline 1970 & 1 & 11.4 \\
\hline 1974 (Feb) & 7 & 21.9 \\
\hline 1974 (Oct) & 11 & 30.4 \\
\hline 1979 & 2 & 17.3 \\
\hline 1983 & 2 & 11.8 \\
\hline 1987 & 3 & 14.0 \\
\hline 1992 & 3 & 21.5 \\
\hline 1997 & 6 & 22.1 \\
\hline 2001 & 5 & 20.1 \\
\hline 2005 & 6 & 17.7 \\
\hline 2010 & 6 & 19.9 \\
\hline 2015 & 56 & 50.0 \\
\hline
\end{tabular}

The SNP won its first seat in a General Election (as opposed to a by-election) in 1970, and it has consistently won seats at every General Election since. Yet, until 2015, its only real breakthrough had been in October 1974, when it had managed to win 11 seats and $30 \%$ of the vote. Though impressive, those results are a far cry from the 56 seats and $50 \%$ of the vote that the SNP won in 2015.

By contrast, the 2015 election was undoubtedly exceptional. The SNP came first at a General Election in Scotland for the first time in its history, and it reached the symbolic barrier of $50 \%$ of the popular vote. Also exceptional about the 2015 election were the big Labour scalps that the SNP took and, in many cases, the size of the swings which the SNP achieved, as the following examples demonstrate. In Paisley \& Renfrewshire South, a traditionally safe Labour seat (under the name Paisley South until 2005) which the SNP took over with $50.94 \%$ of the vote (against Labour's $38.64 \%$ ), twenty -year-old Mhairi Black famously beat senior Labour candidate Douglas Alexander. In the 2010 election, Alexander had won by far with $59.6 \%$ of the vote and the SNP had come second with only 
$18.1 \%$ of the vote. In 2015, the SNP also won the seat of East Renfrewshire (with $40.57 \%$ of the vote against Labour's 34.01\%), a seat which Scottish Labour leader Jim Murphy had held since 1997 (before which it had been a safe Conservative seat). Murphy had won $50.8 \%$ of the vote in 2010 and the SNP had only come fourth with $8.9 \%$ of the vote. In addition to those widely-reported cases (due to the high profile of the losing MPs), some constituencies saw even more impressive swings from Labour to the SNP. Glasgow North East, a normally safe Labour seat (and one of the most deprived constituencies in the UK), saw the largest swing in Scotland (a swing of 39.3\%). The SNP won 58.05\% of the vote (against Labour's 33.69\%), when it had only come a distant second in the previous General Election with $14.1 \%$ of the vote (against Labour's $68 \%$, which had given it a comfortable victory). Also notable were the swings of $36.2 \%$ in Coatbridge, Chryston and Bellshill; 35.2\% in Glasgow South West; 34.9\% in Glenrothes; and 34.6\% in Kirkcaldy \& Cowdenbeath (the former seat of Gordon Brown), to name but a few.

The 2015 Scottish results were clearly singular in the sense that they were different from all previous General Election results in Scotland. However, it remains to be seen whether they were completely unprecedented in the wider sense that they can be compared to no other election results in Scotland.

\section{Comparing General Election and Scottish Parliament election results in Scotland}

A comparison between General Elections in Scotland and Scottish Parliament elections (also known as Holyrood elections) shows that until 2015, both types of elections had given very different results. Party rankings resulting from the number of seats won almost systematically diverged. As was noted earlier, the 1997, 2001, 2005 and 2010 General Elections all saw Labour come first, the Liberal Democrats second, the SNP third and the Conservatives fourth. By contrast, the first two Holyrood elections (in 1999 and 2003) saw Labour come first, the SNP second, the Conservatives third and the Liberal Democrats fourth, while the last two saw the SNP come first, Labour second, the Conservatives third and the Liberal Democrats fourth. In other words, in Holyrood elections, Labour hasn't always been the winning party - it lost the last two elections, by the narrowest of margins (one seat only) in 2007 and then by a wide margin in 2010 while on the other hand, the SNP has always come better than third, which was until 2015 its typical ranking in General Elections. Moreover, while in General Elections, there were hardly any seat changes over the 1997-2010 period, except when forced by a significant reduction in the overall number of Scottish seats in 2005, Scottish Parliament elections have been marked by a steady and marked decline of Labour over the years, as well as by a spectacular rise of the SNP since its low of 2003, as table 4 reveals.

Table 4- Scottish Parliament election results, in terms of seats (total of 129)

\begin{tabular}{|l|l|l|l|l|}
\hline & 1999 & 2003 & 2007 & 2011 \\
\hline Labour & 56 & 50 & 46 & 37 \\
\hline SNP & 35 & 27 & 47 & 69 \\
\hline Conservatives & 18 & 18 & 17 & 15 \\
\hline
\end{tabular}




\begin{tabular}{|l|l|l|l|l|}
\hline Lib Dems & 17 & 17 & 16 & 5 \\
\hline Greens & 1 & 7 & 2 & 2 \\
\hline SSP & 1 & 6 & 0 & 0 \\
\hline SSCUP & - & 1 & 0 & 0 \\
\hline Independents & 1 & 3 & 1 & 1 \\
\hline
\end{tabular}

Labour went from winning 56 seats in 1999 to winning 50 in 2003, 46 in 2007 and finally 37 in 2011. By contrast, after losing seats between 1999 and 2003 (when it went from 35 seats to 27), the SNP gained at least 20 extra seats at each subsequent election (winning a total of 47 seats in 2007 and then a record 69 seats in 2011, a result which gave it a total majority in the Scottish Parliament, the first party to do so since the Parliament's creation).

Holyrood elections have therefore been characterised both by a much greater degree of instability and by tougher electoral competition than General Elections in Scotland. As a consequence, the party systems that have resulted from these two types of elections are very different. General Elections have given birth in Scotland to a "predominant-party system" (to use Giovanni Sartori's phraseology), in other words, a pluralist system in which one party regularly wins an absolute majority of seats in Parliament, though not necessarily a majority of votes. ${ }^{6}$ Scotland has had such a system (with Labour in the role of the predominant party) since the 1960s. Post-May 2015, the question now is whether General Elections will continue to give birth to a predominant-party system in Scotland, but with the SNP having replaced Labour in the role of the predominant party. As for the party system born of Scottish Parliament elections, it has - for the time being - been very different: not a pluralist system with only one big party, but a pluralist system with two big parties (Labour and the SNP), two medium-sized ones (the Conservatives and the Liberal Democrats - though the latter might have become a small party as a consequence of their participation in the 2010-2015 British coalition government), and one small party which has consistently been represented in the Holyrood Parliament, namely the Scottish Greens.

One might object that differences in electoral systems partly explain such differences in outcomes and in party systems. In Holyrood elections, the semi-proportional Additional Member System is used, meaning that Scottish people elect both constituency MSPs (Members of the Scottish Parliament) through the majoritarian First Past the Post system also used for General Elections, and regional MSPs through a proportional list system. In other words, if electoral competition has been tougher in Holyrood elections, it is partly as a result of the differences in electoral systems. However, one element that can be compared directly is the number and share of constituency votes won. Whether one looks at Holyrood election results in terms of constituency votes only, or in terms of both constituency and regional votes, one comes to the same conclusion: voting behaviour has generally differed from voting behaviour in General Elections, as can be seen in table 5 .

Table 5- Scottish voters' order of preference, in terms of votes, in General Elections (GE) and Scottish Parliament elections (SP)

\begin{tabular}{|l|l|l|l|l|l|l|l|l|}
\hline $1997 \mathrm{GE}$ & $1999 \mathrm{SP}$ & $2001 \mathrm{GE}$ & $2003 \mathrm{SP}$ & $2005 \mathrm{GE}$ & $2007 \mathrm{SP}$ & $2010 \mathrm{GE}$ & $2011 \mathrm{SP}$ & $2015 \mathrm{GE}$ \\
\hline
\end{tabular}




\begin{tabular}{|l|l|l|l|l|l|l|l|l|}
\hline Labour/ & Labour/ & Labour/ & Labour/ & Labour/ & SNP/ & Labour/ & SNP/ & SNP/ \\
SNP/ & SNP/ & SNP/ & SNP/ & Lib D/ & Labour/ & SNP/ & Labour/ & Labour/ \\
Tories/ & Tories/ & Lib D/ & Tories/ & SNP/ & Tories/ & Lib D/ & Tories/ & Tories/ \\
Lib D/ & Lib D/ & Tories/ & Lib D/ & Tories/ & Lib D/ & Tories/ & Lib D/ & Lib D/ \\
Others & Others & Others & Others & Others & Others & Others & Others & Others \\
\hline
\end{tabular}

NB: in the case of Holyrood elections, the order of preference is the same whether one considers constituency votes only, or both constituency and regional votes.

Until 2015, Scottish people had always voted differently in Holyrood elections from how they had voted in the General Elections that immediately preceded them, except in the very first one, in 1999, when people were new to voting for the Scottish Parliament.

Let us now compare the 2015 General Election to the Holyrood election that preceded it (which occurred in 2011), so as to establish to what extent the 2015 result was unprecedented. Such a comparison reveals that the 2015 General Election was less exceptional than commentators unfamiliar with Scottish politics might have thought, as to a large extent, it was the result of a convergence in voting behaviour for Scottish Parliament elections and General Elections. This convergence is apparent in at least two respects. First of all, Scottish voters' party rankings were identical in 2011 and 2015: in both cases, their order of preference was SNP/ Labour/ Conservatives/ Liberal Democrats/ Others (as can be seen in table 5). As was noted earlier, such convergence in voting behaviour had only happened once in the past, on the occasion of the 1997 General Election and the 1999 Holyrood election. Secondly, in both elections, the SNP won very comfortably over the Labour Party: the margin of the SNP victory was colossal in 2015 (50.0\% of the vote against Labour's $24.3 \%$ ), but it had already been very significant in 2011 ( $45.4 \%$ of the constituency vote against Labour's 31.7\%), as table 6 shows. Moreover, the same table reveals that the share of the vote won by the medium-sized parties (the Conservatives and the Liberal Democrats) was very similar in 2011 and 2015. The small parties (the Greens, for instance) do not tend to field constituency candidates in Holyrood elections, preferring to concentrate their efforts on winning regional list votes, meaning that a comparison between General Elections and Holyrood elections is in their case impossible.

Table 6- Results of the 2011 Scottish Parliament election (constituency votes only) and the 2015 General Election in Scotland: number of votes and share of the vote

\begin{tabular}{|l|l|l|}
\hline & $\begin{array}{l}\text { 2011 Scottish Parliament election (constituency } \\
\text { votes only) } \\
\text { Number of votes (share of the vote in \%) }\end{array}$ & $\begin{array}{l}\text { lo15 General Election } \\
\text { Scotland) } \\
\text { Number of votes (share of the } \\
\text { vote) }\end{array}$ \\
\hline SNP & $\begin{array}{l}902,915 \\
(45.4 \%)\end{array}$ & $\begin{array}{l}1,454,436 \\
(50.0 \%)\end{array}$ \\
\hline Labour & $\begin{array}{l}630,437 \\
(31.7 \%)\end{array}$ & $\begin{array}{l}707,147 \\
(24.3 \%)\end{array}$ \\
\hline Conservatives & 276,652 & $\begin{array}{l}434,097 \\
(14.9 \%)\end{array}$ \\
\hline Liberal & $(13.9 \%)$ & $\begin{array}{l}219,675 \\
(7.5 \%)\end{array}$ \\
\hline Democrats & $(7.9 \%)$ & \\
\hline
\end{tabular}




\begin{tabular}{|l|l|l|}
\hline UKIP & - & $\begin{array}{l}47,078 \\
(1.6 \%)\end{array}$ \\
\hline Greens & - & $\begin{array}{l}39,205 \\
(1.3 \%)\end{array}$ \\
\hline Others & 21,534 & $\begin{array}{l}8,827 \\
(0.3 \%)\end{array}$ \\
\hline
\end{tabular}

Thirdly, and more generally, we might be witnessing a convergence in party systems for both types of elections. Since the 2015 General Election result, several senior Scottish politicians (such as Lord Steel for instance ${ }^{7}$ ) have warned of the dangers of Scotland becoming a "one-party state" - or rather, in more technical terms, a predominant-party state, according to Sartori's classification of party systems. ${ }^{8}$ Will the next Scottish Parliament election confirm that Scotland has become a predominant-party polity for both General Elections and Holyrood elections? At the time when this article was written, polls suggested that the SNP would confirm its dominant position in 2016 and that Labour would continue to lose seats. The results of a poll made public on 9 June 2015 and carried out between 13 and 30 May 2015 are presented in table $7 .{ }^{9}$

Table 7- Possible results of the 2016 Holyrood election (TNS survey of 1031 Scots aged over 16 between 13 and 30 May 2015)

\begin{tabular}{|l|l|l|l|}
\hline & Constituency vote & Regional vote & Seats \\
\hline SNP & $60 \%(+15 \mathrm{pts})$ & $50 \%(+6 \mathrm{pts})$ & $73(+4)$ \\
\hline Labour & $19 \%(-13 \mathrm{pts})$ & $19 \%(-7 \mathrm{pts})$ & $25(-12)$ \\
\hline Conservatives & $15 \%(+1 \mathrm{pt})$ & $14 \%(+2 \mathrm{pts})$ & $17(+2)$ \\
\hline Greens & - & $10 \%(+6 \mathrm{pts})$ & $10(+8)$ \\
\hline Lib Dems & $3 \%(-5 \mathrm{pts})$ & $5 \%($ no change $)$ & $4(-1)$ \\
\hline UKIP & - & $2 \%(+2 \mathrm{pts})$ & 0 \\
\hline
\end{tabular}

Predicted turnout: $67 \%$ (+17 pts).

The SNP could win an incredible share of the vote in 2016: 60\% of constituency votes, which is unheard of for any party in any election in Scotland, and even $50 \%$ of regional votes. This could translate into a total of 73 seats out of 129 in the Scottish Parliament. This would represent a huge majority considering the fact that the electoral system is partly proportional. As for Labour, it could lose 12 seats, including all of its constituency seats (meaning that all of its seats would come from the regional lists).

\section{Explaining the convergence in Scottish voting behaviour}

The convergence in Scottish people's voting behaviour in General Elections and Holyrood elections leaves us with two questions. First of all, why have we witnessed such a convergence? Several factors may have led to this outcome. One explanation for the 2015 General Election results might seem obvious: it is what we could call the "referendum 
effect". The SNP's spectacular general election results are to be seen in the context of the equally spectacular rise in its membership - and in the memberships of all the proindependence parties - since the failure of the Scottish independence referendum of September 2014. In other words, the parties that lost the referendum seem to have won the political argument. The SNP in particular has clearly benefitted from the long referendum campaign, while Labour has suffered from it, in large part because of its awkward association with the Conservative Party under the "Better Together" banner.

However, it would be wrong to see the General Election results through the sole angle of the "referendum effect". The collapse of Labour and the rise of the SNP in Scotland have deeper roots. One of these roots could be a form of "Labour fatigue": Scottish people have voted Labour at every single General Election in half a century - as well as regularly voting Labour in other types of elections - and they have now found in the SNP what they see as a suitable centre left alternative. Another explanation lies in the parties themselves and in their internal structure and way of functioning. The rise of the SNP was made possible by its structural reforms of 2004, carried out under John Swinney, which led to its professionalization and (as was argued at the time) its modernisation. ${ }^{10}$ These reforms were instrumental to the party's first electoral victory in 2007. Concerning Labour, many Scottish Labour members believe the party's decline north of the Border is mainly due to its lack of structural autonomy from the central Labour executive. When Scottish Labour leader Johann Lamont resigned a few weeks after the independence referendum, she called on the Labour Party as a whole to "recognise that the Scottish party has to be autonomous and not just a branch office of a party based in London". ${ }^{11}$ More specifically, Scottish Labour should "be allowed to make [its] own decisions and control [its] own resources." She also accused some of her Westminster colleagues of being "dinosaurs [...] who think nothing has changed", a metaphor which was later taken up by another senior Scottish Labour member, Andy Kerr, ${ }^{12}$ who warned in an online article that "the tectonic plates have shifted. We have a new normal [sic], and we can die like the dinosaurs, or we can embrace change and survive". He agreed with Lamont that "[t]he seeds of Labour's wipeout were sown long ago and were the predictable consequence of our failure to devolve the political culture of the Scottish Labour party to match our devolved powers." ${ }^{13}$ To him, Scottish Labour needed to "base its party machine in Edinburgh and develop a closer relationship with the Scottish Parliament. Labour could then rebuild through the parliament, local government and the community." He also argued that Scottish Labour was to the left of Labour as whole ("Our instincts are more communitarian, cooperative, pro-public service, pro-European, anti-Trident, and, most importantly, anti-austerity"), and that this was something which should be celebrated. In summary, the idea developed by several Scottish Labour members is that Scottish Labour should reinforce and celebrate its difference and its autonomy, both in terms of structure and in terms of ideology.

\section{Conclusion}

The second and final question that the convergence in Scottish voting behaviour for Holyrood and General Elections leaves us with is the following: will this convergence be temporary or long-lasting, and will it continue to concern General Elections and Holyrood elections only? In other words, will the SNP become the main party in Scotland whatever the election? Table 8 reveals the SNP and Labour's latest election results for all elections concerning Scotland. 
Table 8- The SNP and Labour's latest election results in Scotland

\begin{tabular}{|l|l|l|l|l|}
\hline & $\begin{array}{l}\text { Scottish } \\
\text { Parliament } \\
(2011)\end{array}$ & $\begin{array}{l}\text { Local councils } \\
(2012)\end{array}$ & $\begin{array}{l}\text { European Parliament } \\
(2014)\end{array}$ & $\begin{array}{l}\text { British Parliament } \\
(2015)\end{array}$ \\
\hline SNP & $\begin{array}{l}69 \text { seats out of } 129 \\
(+22)\end{array}$ & $\begin{array}{l}425 \text { seats out of } \\
1,223(+62)\end{array}$ & $\begin{array}{l}2 \text { seats out of } 6 \\
(+0)\end{array}$ & $\begin{array}{l}56 \text { seats out of } 59 \\
(+50)\end{array}$ \\
\hline Labour & $\begin{array}{l}37 \text { seats out of } 129 \\
(-9)\end{array}$ & $\begin{array}{l}394 \text { seats out of } \\
1,223(+46)\end{array}$ & $\begin{array}{l}2 \text { seats out of } 6 \\
(+0)\end{array}$ & 1 seat out of $59(-40)$ \\
\hline
\end{tabular}

Besides the Holyrood election and the General Election, the SNP also came first in the latest local elections in Scotland. However, though it is true that Labour came second in the local elections, it should be noted there was an overall increase in the number of Labour councillors elected (compared to 2007). Secondly, the SNP didn't manage to beat Labour in the latest European election, in 2014, when it had hoped to win a third seat which went to UKIP instead.

Therefore Scotland is not yet a predominant-party polity for all elections. It is however undeniable that the SNP's current majorities in the Scottish Parliament and in the Scottish group of MPs at Westminster are huge. Even more worryingly for the Labour Party, Scottish people seem to have stopped (at least for the time being) voting tactically for Labour in General Elections. The key question for the party is therefore whether it is becoming the new "nasty party" in Scotland, ${ }^{14}$ a phrase which used to be reserved for the Conservative Party. Labour's general election rout in Scotland is reminiscent of the Conservatives' total Scottish wipeout of 1997, from which it still hasn't recovered, almost 20 years later, which is a rather ominous sign for Labour in Scotland.

\section{BIBLIOGRAPHY}

GARDHAM, Magnus. "Poll: $60 \%$ of Voting Scots Intend to Support SNP in Next Year's Holyrood Election", The Herald, 9 June 2015.

GREAT BRITAIN HOUSE OF COMMONS. Debates. 8 June 2015, vol.596, col.919.

RIDDOCH, Lesley. “Will Labour Face their own Portillo Moment?”, 5 February 2015.

SARTORI, Giovanni. Parties and Party Systems: A Framework for Analysis. Cambridge: Cambridge University Press, 1976.

SETTLE, Michael. "Lord Steel Warns of Danger of 'One-Party State' in Scotland", The Herald, 25 June 2015.

STURGEON, Nicola. "We, the Scottish People, Cannot Now be Ignored”, The Guardian, 9 May 2015.

Daily Record, http://www.dailyrecord.co.uk/news/politics/johann-lamont-resigns-scottishlabour-4502765. 
Labour Hame website, http://labourhame.com/autonomy-split-the-difference/ .

\section{NOTES}

1. Nicola Sturgeon, “We, the Scottish People, Cannot Now be Ignored”, Guardian, 9 May 2015.

2. Great Britain House of Commons debate, 8 June 2015, vol.596, col.919.

3. Ibid., col.951.

4. Ibid.

5. As noted previously, Labour retained the seat of Edinburgh South. The Conservative Party retained that of Dumfriesshire, Clydesdale and Tweeddale, and the Liberal Democrats the seat of Orkney \& Shetland.

6. Giovanni SARTORI, Parties and Party Systems: A Framework for Analysis, Cambridge: Cambridge University Press, 1976. For a French version of the same book, see: Partis et systèmes de partis. Un cadre d'analyse, Bruxelles : Editions de l'Université de Bruxelles, 2011. See page 289 of the edition in French for a definition of his concept of "predominant-party system".

7. See for instance Michael SETTLE, “Lord Steel Warns of Danger of 'One-Party State' in Scotland", The Herald, 25 June 2015.

8. SARTORI, op. cit. The phrase "single-party states" is not applicable either, as to him, those are states where only one party has the right to form a government.

9. See Magnus GARDHAM, "Poll: $60 \%$ of Voting Scots Intend to Support SNP in Next Year's Holyrood Election", The Herald, 9 June 2015. There is one slight mistake in the Herald article: if the SNP won $60 \%$ of the constituency vote in 2016 , this would correspond to a rise in 15 percentage points, not 10 as indicated.

10. Two examples of reforms introduced at the time are the use of "one-member-one-vote" for the election of party leader and the fact that it became much more difficult to challenge the position of party leader.

11. Interview for the Daily Record, http://www.dailyrecord.co.uk/news/politics/johann-lamontresigns-scottish-labour-4502765. Accessed on 27 July 2015.

12. Andy Kerr was Scottish Minister for Health and Community Care in 2004-2007.

13. http://labourhame.com/autonomy-split-the-difference/. Accessed on 27 July 2015.

14. As suggested by Lesley Riddoch in an article for the National newspaper ("Will Labour Face their own Portillo Moment?", 5 February 2015).

\section{ABSTRACTS}

The 2015 General Election outcome in Scotland was historic, for several reasons: the SNP won a General Election in Scotland for the first time, it won almost all Scottish seats, and Labour did not win for the first time in half a century. The aim of this paper is to put this undeniably historic outcome into context and into perspective, through an analysis of General Election results in Scotland since 1997 and a comparison between those results and Scottish Parliament election results. It will be argued that besides the obvious ones, the 2015 election outcome was exceptional for another, less obvious reason, namely that it was the result of a convergence in voting behaviour in Scotland for General Elections and for Holyrood elections. 
En Écosse, c'est un résultat indéniablement historique qui sortit des urnes à l'occasion des élections législatives britanniques de 2015 (victoire du SNP en Écosse à ce type d'élections pour la première fois de son histoire, victoire massive puisqu'il remporta la quasi-totalité des sièges écossais, et défaite du parti travailliste pour la première fois en cinquante ans). Cependant, cet article s'emploie à mettre ce scrutin en perspective, par une étude des résultats des élections législatives britanniques en Écosse depuis 1997, ceux-ci étant ensuite comparés aux résultats des élections législatives proprement écossaises (celles qui concernent le Parlement écossais et non plus la Chambre des Communes britannique). L'argument avancé est que le caractère exceptionnel des élections de 2015 en Écosse provient aussi d'une autre raison moins évidente, à savoir que celles-ci furent le signe d'une convergence des comportements électoraux des Écossais pour les deux types d'élections législatives qui les concernent (les britanniques et les écossaises).

\section{INDEX}

Mots-clés: comportement électoral, élections législatives britanniques, élections législatives écossaises

Keywords: voting behaviour, General Elections, Scottish Parliament elections

\section{AUTHOR}

\section{NATHALIE DUCLOS}

Université de Toulouse 2-Jean Jaurès 